\title{
Mitigation of As accumulation in paddy rice (Oryza sativa L.) by amendments containing iron and manganese
}

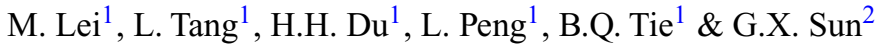 \\ ${ }^{1}$ College of Resource and Environment, Hunan Agricultural University, Changsha, P.R. China \\ ${ }^{2}$ State Key Laboratory of Urban and Regional Ecology, Research Center for Eco-Environmental Sciences, \\ Chinese Academy of Sciences, Beijing, P.R. China
}

\begin{abstract}
In order to mitigate As accumulation in rice, amendments such as iron ore tailing (FeT) and manganese ore tailing (MnT) were employed in As contaminated soil. Before experiment, the toxicities of both amendments were assessed with Toxicity Characteristic Leaching Procedure (TCLP) and horizontal vibration method (HVM), respectively. The ranges of contents of As were $0.13-1.54 \mathrm{mg} \mathrm{kg}^{-1}$ in husk samples, and $0.06-$ $0.42 \mathrm{mg} \mathrm{kg}^{-1}$ in brown rice, respectively. Among both amendments treatment, the lowest concentrations of As in rice grain were found by MnT treatment due to its structure and composition. There was significantly negative relation $(\mathrm{p}<0.05)$ between $\mathrm{Mn}$ and As, while significantly positive relationship between Fe and As, and ratio of $\mathrm{Fe} / \mathrm{Mn}$ and $\mathrm{As}$ in rice plant $(\mathrm{p}<0.05)$.
\end{abstract}

\section{INTRODUCTION}

Iron $(\mathrm{Fe})$ and manganese $(\mathrm{Mn})$ are the first $\left(5.6 \times 10^{4} \mathrm{mg} \mathrm{kg}^{-1}\right)$ and third $\left(9.5 \times 10^{2} \mathrm{mg} \mathrm{kg}^{-1}\right)$ most abundant transition metals in the earth's crust (Cox, 1995). Due to the redox chemistries of Fe (II/III) and $\mathrm{Mn}(\mathrm{II} / \mathrm{III} / \mathrm{IV})$ having important roles and impacts in the environment (Stone and Morgan, 1987), Fe and Mn oxides and hydroxides have been incorporated into metal-contaminated soil, especially for controlling As adsorption-desorption reactions in soil. Moreover, arsenic is a toxic and ubiquitous element in the environment, especially in rice plants because rice easily uptakes As from soil, even in uncontaminated soil compared to other cereals under reduced conditions. The aim of this study was to study the effects of $\mathrm{Fe}$ and $\mathrm{Mn}$ from FeT and MnT on As uptake by rice plant and transfer from soil to rice and assess the toxicity of $\mathrm{FeT}$ and MnT with the toxicity characteristic leaching procedure (TCLP) of USA and horizontal vibration method (HVM) of China before pot experiment.

\section{METHODS/EXPERIMENTAL}

\subsection{Materials}

The paddy soils $(0-20 \mathrm{~cm})$ were collected from one smelting-impacted area in Chenzhou city, Hunan province. The amendments such as iron mine tailing $(\mathrm{FeT})$ and manganese mine tailing $(\mathrm{MnT})$ were collected from Xiangxiang iron work and Xiangxi manganese ore factory, respectively. Both amendments were grounded and passed through a $2-\mathrm{mm}$ sieve. The dry samples of FeT and MnT were characterized by SEM-EDAX under KV 20.0, Mag 1000, TILT 0.0 , Micronsperpixy 0.119 conditions. Moreover, the toxicities of both amendments were assessed with toxicity characteristic leaching procedure (TCLP) and horizontal vibration method (HVM), respectively.

\subsection{Experiment design and sample collection}

Before rice was planted, each pot was filled with $5.0 \mathrm{~kg}$ soil, mixed with either FeT $(0.0 \%, 1.0 \%$, and $2.0 \%)$ and $\mathrm{MnT}(0.0 \%, 1.0 \%$, and $2.0 \%)$, respectively. The aging time was 30 days. At the start of the pot experiment, the solid fertilizers $\left(0.36 \mathrm{~g} \mathrm{~kg}^{-1}\right.$ soil of $\mathrm{CaH}_{2} \mathrm{PO}_{4} \cdot 2 \mathrm{H}_{2} \mathrm{O}, 0.43 \mathrm{~g} \mathrm{~kg}^{-1}$ soil of $\mathrm{CO}\left(\mathrm{NH}_{2}\right)_{2}$, and $0.41 \mathrm{~g} \mathrm{~kg}^{-1}$ soil of $\mathrm{KCl}$ ) were added to ensure adequate nutrition for the growth of rice seedlings. About $3-4 \mathrm{~cm}$ water above the soil level in the pot was maintained 2 days before seedling transplantation. Growth of rice plants continued for 4 months. Plants were watered with distilled water $(18 \mathrm{~m} \Omega$, Millipore) without heavy metals and fertilizer, one to two times per week. Pots were designed with four replications, randomized and alternated weekly in greenhouse. At harvest, Rice grains were separated from the plant by handpicking, straws were cut at $4 \mathrm{~cm}$ above the soil, and roots were pulled out from the paddy soil. Iron plaque on fresh root surfaces was extracted using dithionite-citrate-bicarbonate (DCB) solution according to the method of Taylor and Crowder (1983). All rice plant samples were tagged, stored in polyethylene bags, and transported to the laboratory within $4 \mathrm{~h}$ for sample processing. 


\section{RESULTS AND DISCUSSION}

\subsection{As contents in paddy soil and both amendments}

The soil As content with $62.54 \mathrm{mg} \mathrm{kg}^{-1}$ was 2.5 times higher than the national standard value $\left(25.0 \mathrm{mg} \mathrm{kg}^{-1}\right)$ for paddy soil in China. The total As concentrations in FeT $\left(33.43 \mathrm{mg} \mathrm{kg}^{-1}\right)$ and $\mathrm{MnT}\left(20.54 \mathrm{mg} \mathrm{kg}^{-1}\right)$ were lower than that in agricultural use (GB42841984), while much higher than the world As mean value, which suggested that FeT and MnT should be pre-treated before utilization.

Figure 1 demonstrated that the particles of MnT were not dense and seems to be constituted of an agglomeration of plate or lamellar particles. The SEM showed that the MnT (a) adsorbed As better than that of $\mathrm{FeT}(\mathrm{b})$. There were many elements such as $\mathrm{Fe}, \mathrm{Mg}, \mathrm{Al}$, $\mathrm{Si}, \mathrm{Ca}, \mathrm{O}$ and $\mathrm{C}$ in $\mathrm{FeT}$ (c), while only three elements like $\mathrm{Mn}, \mathrm{O}$ and $\mathrm{C}$ were found in $\mathrm{MnT}$ (d).

The extraction of As concentrations from $\mathrm{FeT}$ and MnT with TCLP were much higher than those with HVM. It was observed that the As contents in extract liquids with both regents from FeT and MnT in TCLP exceed that allowable regulatory limit $0.1 \mathrm{mg} \mathrm{L}^{-1}$, and were much higher than those leached with HVM due to the low $\mathrm{pH}$ (2.9) of the leachate solution 2 in TCLP. Judged by Chinese identification standards for hazardous wastes-identification for extraction toxicity (GB5085.3-2007), the FeT and MnT employed in present study should be pretreated with distilled water until As and other metals weren't determined in extract solution.

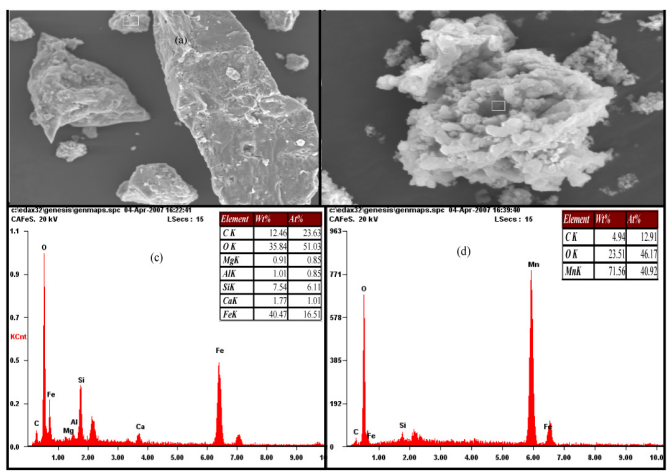

Figure 1. Images of surface FeT (a) and MnT (b) with SEM, and quantitative compositions of FeT (c) and MnT (d) with EDAX.

\subsection{Relationship between $\mathrm{Mn}$ and Fe in rice plant}

The significantly negative relationship between $\mathrm{Mn}$ and $\mathrm{Fe}$ was found in rice plant $(p<0.05)$, indicating that increasing Mn concentrations caused Fe concentration to decrease in rice plant. Among all parts of rice plant, the highest concentrations of Fe (27077.62$47804.89 \mathrm{mg} \mathrm{kg}^{-1}$ ) were found in DCB corresponding addition dosages, followed by Mn (4761.70 $5492.93 \mathrm{mg} \mathrm{kg}^{-1}$ ). The rice root, especially root surface accumulated Fe concentrations with 1279.68$47804.89 \mathrm{mg} \mathrm{kg}^{-1}$ were almost 10 -time higher than those of Mn (116.58-5492.93 $\left.\mathrm{mg} \mathrm{kg}^{-1}\right)$. While, the concentrations of $\mathrm{Mn}$ in straw and grain were higher than those of Fe. The transfer factors (TFs) of Mn ranged 0.74-1.93 from root to rice plant above ground, and ranged from $0.35-0.43$ from straw to grain, while the TFs of Fe were 0.01-0.02 from root to rice plant above ground, and ranged from $0.10-0.25$ from straw to grain, indicating the TFs of Mn were higher those of $\mathrm{Fe}$ in rice plant.

\subsection{Concentrations of $A s, F e$, and $M n$ in rice grain}

The ranges of As concentrations in husk samples were $0.13-1.54 \mathrm{mg} \mathrm{kg}^{-1}$, and in brown rice were $0.06-0.42 \mathrm{mg} \mathrm{kg}^{-1}$, respectively (Table 1 ). Comparison of $\mathrm{CK}$, the contents of As in husk and brown rice were not significantly reduced with increasing amounts of $\mathrm{FeT}$ and $\mathrm{MnT}(p=0.39>0.05)$. The distribution of As in the soil-rice plant system with unamend $(\mathrm{CK})$ and $\mathrm{FeT}$ treatment followed: DCB $>$ root $>$ soil $>$ straw $>$ husk $>$ brown rice, indicating As contents in DCB (225.57-286.78 $\mathrm{mg} \mathrm{kg}^{-1}$ ) were much higher than that of soil $\left(62.54 \mathrm{mg} \mathrm{kg}^{-1}\right)$. However, due to the high Mn concentrations in DCB solution, the order of As distribution was: root $>$ soil $>$ DCB $>$ straw $>$ husk $>$ brown rice with MnT treatment. Among both amendments, the concentrations of As in husk and brown rice were the lowest, especially treatment with $2.0 \%$ of $\mathrm{MnT}$, with $0.13 \mathrm{~m} \mathrm{~kg}^{-1}$ and $0.06 \mathrm{mg} \mathrm{kg}^{-1}$ in husk and brown rice, indicating the MnT was the best material for controlling As transfer from soil to rice plant.

\section{CONCLUSIONS}

There was significantly negative relationship between $\mathrm{Fe}$ and $\mathrm{Mn}$, and $\mathrm{Mn}$ and $\mathrm{As}$ in rice plant, while, there

Table 1. Contents of $\mathrm{Mn}$ and $\mathrm{Fe}$ in husk and brown rice.

\begin{tabular}{|c|c|c|c|c|c|c|}
\hline \multirow[b]{2}{*}{ Treatment } & \multicolumn{3}{|c|}{ Husk (mg kg ${ }^{-1}$ ) } & \multicolumn{3}{|c|}{ Brown rice $\left(\mathrm{mg} \mathrm{kg}^{-1}\right)$} \\
\hline & As & $\mathrm{Fe}$ & Mn & As & $\mathrm{Fe}$ & Mn \\
\hline $\mathrm{CK}$ & $1.54 \pm 0.24$ & $25.46 \pm 1.69$ & $275.11 \pm 8.95$ & $0.42 \pm 0.11$ & $6.46 \pm 0.12$ & $13.92 \pm 1.42$ \\
\hline $1.0 \% \mathrm{FeT}$ & $1.23 \pm 0.21$ & $41.58 \pm 2.28$ & $254.93 \pm 54.00$ & $0.34 \pm 0.16$ & $8.91 \pm 1.32$ & $13.58 \pm 0.59$ \\
\hline $2.0 \% \mathrm{FeT}$ & $1.11 \pm 0.41$ & $51.89 \pm 10.45$ & $278.71 \pm 63.12$ & $0.28 \pm 0.10$ & $17.76 \pm 1.45$ & $15.09 \pm 4.64$ \\
\hline $1.0 \% \mathrm{MnT}$ & $0.49 \pm 0.04$ & $33.07 \pm 4.17$ & $676.71 \pm 179.23$ & $0.09 \pm 0.01$ & $2.67 \pm 0.75$ & $39.12 \pm 4.06$ \\
\hline $2.0 \% \mathrm{MnT}$ & $0.13 \pm 0.01$ & $21.57 \pm 2.63$ & $605.85 \pm 142.16$ & $0.06 \pm 0.02$ & $5.18 \pm 1.72$ & $37.88 \pm 0.42$ \\
\hline
\end{tabular}


was positive correlation between $\mathrm{Fe}$ and $\mathrm{As}$, and the ratio of $\mathrm{Fe} / \mathrm{Mn}$ and $\mathrm{As}$ in rice plant. After application of both amendments, the soil $\mathrm{pH}$ increased, and the As contents in rice grain decreased, especially Mn mine tailing is the best material for controlling As transfer from soil to rice plant due to transfers factor of $\mathrm{Mn}$ higher than that of Fe.

\section{ACKNOWLEDGEMENTS}

This work was supported by the National Science Foundation of China (41671475/21007014).

\section{REFERENCES}

Cox P.A. 1995. The Elements on Earth: Inorganic Chemistry in the Environment. New York, Oxford University Press.

Stone A.T. \& Morgan J.J. 1987. Reductive dissolution of metal oxides, In: W. Stumm (ed) Aquatic Surface Chemistry. New York: Wiley, pp. 221-254.

Taylor G.J. \& Crowder A.A. 1983. Use of DCB technique for extraction of hydrous iron oxides from roots of wetland plants. Am. J. Bot. 70: 1254-1257. 